\title{
The Launch of the Euro
}

Carol C. Bertaut and Murat F. Iyigun, of the Board's Division of International Finance, prepared this article. Tim Troha provided research assistance.

The introduction on January 1, 1999, of the eurothe single currency adopted by eleven of the fifteen countries of the European Union-marked the beginning of the final stage of Economic and Monetary Union and the start of a new era in Europe. This historic achievement was the culmination of a lengthy process that began in March 1957, when six European nations-Belgium, France, Germany, Italy, Luxembourg, and the Netherlands-signed the Treaty of Rome, thereby founding the European Economic Community (EEC). ${ }^{1}$ The Treaty came into effect on January 1, 1958, exactly forty-one years before the inception of the new single European currency. ${ }^{2}$

Although the Treaty of Rome created a closer economic union among member countries, these countries did not at the time envisage an actual monetary union. In 1971, a group of European experts developed a proposal for coordinated or harmonized monetary policy among EEC members; this proposal was made explicit in the Werner plan. Further progress toward monetary integration was set in motion by the establishment in 1979 of a system of stable, but adjustable, exchange rates known as the European Monetary System. The first major revision to the Treaty of Rome was the Single European Act, signed in 1986, which affirmed old objectives and set new ones, including the establishment of a European single market and the gradual realization of monetary union. In 1989, specific stages toward achieving Economic and Monetary Union (EMU) were detailed in the Delors Committee report, and in December 1991 in the Dutch city of Maastricht, European Union

1. The Treaty of Rome was preceded in 1951 by the Treaty of Paris to which the same six European nations were signatories; the Treaty of Paris established the European Coal and Steel Community, which aimed at the more-limited objective of pooling the coal and steel resources of member countries.

2. Over the years, membership in the EEC, which was renamed the European Union, grew from the initial six countries to fifteen, with Denmark, Ireland, and the United Kingdom becoming full members in 1973, Greece in 1981, Spain and Portugal in 1986, and Austria, Finland, and Sweden in 1995.
1. Comparison of the euro area and the United States Percent except as noted

\begin{tabular}{|c|c|c|}
\hline Item & Euro area & United States \\
\hline Population (1997, millions) & 282 & 268 \\
\hline Nominal GDP (1998, trillions of dollars) & 6.6 & 8.5 \\
\hline $\begin{array}{l}\text { Inflation (June 1999, twelve-month } \\
\text { percent change) }{ }^{1} \ldots \ldots \ldots \ldots \ldots \ldots\end{array}$ & 9 & 2.0 \\
\hline Unemployment rate (July 1999) ${ }^{2}$. & 10.3 & 4.3 \\
\hline Exports as a share of GDP (1998) & 33.7 & 11.3 \\
\hline Excluding intra-euro-area trade & 13.5 & \\
\hline Imports as a share of GDP (1998) & 31.5 & 13.0 \\
\hline Excluding intra-euro-area trade & 12.1 & $\ldots$ \\
\hline
\end{tabular}

1. Euro-area harmonized inflation is calculated from a weighted average of harmonized consumer price indexes for individual countries. The harmonized indexes are constructed by standardizing some aspects of statistical practice and eliminating categories from national consumer price indexes, leaving indexes with basically identical coverage across countries.

2. Euro-area unemployment estimates are based on the results of the European Community Labour Force Survey.

.. . Not applicable.

(EU) nations produced the Treaty on European Union. ${ }^{3}$

This treaty, generally referred to as the Maastricht Treaty, became the effective "constitution" for EMU, providing the criteria for judging macroeconomic convergence and laying the groundwork for the eventual establishment of the European Central Bank. ${ }^{4}$ In early May 1998, the heads of state or government of the fifteen EU countries agreed that eleven countries (Austria, Belgium, Finland, France, Germany, Ireland, Italy, Luxembourg, the Netherlands, Portugal, and Spain) should move forward into the final stage of EMU, creating an economic area comparable in size to that of the United States (table 1). The European Commission of the European Union and the European Monetary Institute evaluated each country's readiness for entry on the basis of the

3. For further background on the stages leading up to EMU, see Hervé Carré and Karen H. Johnson, "Progress toward a European Monetary Union," Federal Reserve Bulletin, vol. 77 (October 1991), pp. 769-83; Peter Kenen, Economic and Monetary Union in Europe: Moving beyond Maastricht (Cambridge University Press, 1995), and Robert Solomon, Money on the Move: The Revolution in International Finance since 1980 (Princeton University Press, 1999).

4. The Maastricht Treaty also provided the legal basis for the European Central Bank and protocols for the European System of Central Banks (ESCB) and the European Monetary Institute (EMI). The ESCB comprises the European Central Bank and the fifteen EU-member national central banks. The EMI was the precursor to the ECB. During its transitory existence between January 1994 and July 1998, the EMI worked to strengthen cooperation and monetary policy coordination among national central banks and to facilitate preparations for the establishment of the ESCB. 
performance criteria for inflation, fiscal policy, longterm interest rates, and exchange rates and on the conformity of each country's national central bank legislation with the Maastricht Treaty. The European Central Bank came into formal existence on June 1, 1998, and took over responsibility for the monetary policy of the EMU member states on January 1, 1999.

The creation of a single currency and a single monetary policy has provided both extraordinary challenges and exceptional opportunities within Europe. A new financial infrastructure was necessary to handle transactions in the new currency. Although the euro does not yet exist as a physical currencybank notes and coins will not be introduced until 2002 - the euro is traded in financial markets, new issues of securities are denominated in euros, and official statistics in the euro area are quoted in the euro (table 2). For financial firms, the creation of the euro required conversion of numerous existing accounts and systems for trading, risk analysis, and liquidity management to the new currency. Although development of these systems had been ongoing for several years, the actual switchover took place over the long "conversion weekend" from the close of business on December 31, 1998, through the opening of business on January 4, 1999. Round-the-clock efforts in major financial centers were necessary for handling the complexities of re-denominating euroarea government bonds to the new currency, converting financial accounts, and doing final testing of the system for interbank payments. Now that the initial transition has been successfully completed, the establishment of the single monetary area and the removal of currency risk among member countries is expected to provide unprecedented opportunities for crossborder trading, portfolio expansion, and mergers and acquisitions among European companies.

This article reviews the organization, objectives, and targets of the euro area's new central bank and discusses some of the early challenges it has faced in setting and implementing monetary policy with the new common currency. It discusses the initial functioning of the payment system and the interbank market and reviews the effects to date of the single currency on European bond and equity markets, on the banking system, and in euro-area transactions.

\section{ORGANIZATION OF THE NEW EUROPEAN CENTRAL BANK AND THE EUROSYSTEM}

With the start of the final stage of EMU, monetary policy is no longer set individually at each of the
2. Official currency conversion rates

\begin{tabular}{|c|c|c|}
\hline Country & Currency & Currency units per euro \\
\hline Austria & schilling & 13.7603 \\
\hline Belgium & franc & 40.3399 \\
\hline Finland & markka & 5.94573 \\
\hline France . & franc & 6.55957 \\
\hline Germany & mark & 1.95583 \\
\hline Ireland . & punt & .787564 \\
\hline Italy & lira & 1936.27 \\
\hline Luxembourg & franc & 40.3399 \\
\hline Netherlands & guilder & 2.20371 \\
\hline Portugal & escudo & 200.482 \\
\hline Spain ... & peseta & 166.386 \\
\hline
\end{tabular}

SourCE. European Central Bank.

national central banks of the euro-area countries. Instead, monetary policy is determined for the euro area as a whole by the Eurosystem. The Eurosystem comprises the new European Central Bank (ECB) at its center as well as the national central banks of the eleven countries currently participating in the monetary union. ${ }^{5}$ The Maastricht Treaty grants the ECB full constitutional independence. It explicitly states that neither the ECB nor any member of its decisionmaking bodies shall seek or take instructions from European Commission institutions, from any government of a member state, or from any other organization or institution. The primary decisionmaking bodies of the ECB are the Executive Board and the Governing Council. The Executive Board consists of the president and vice president of the ECB and four other members (table 3). These members are appointed by common agreement among the governments of EMU member states on a recommendation from the EU Council after consulting with the European Parliament. The members of the Executive Board are also members of the Governing Council, along with the governors of the national central banks of the eleven EMU member countries. The primary responsibility of the Governing Council is the setting of monetary policy within the euro area. The primary responsibility of the Executive Board is to implement monetary policy and to issue instructions as necessary to the national central banks in accordance with the guidelines of the Governing Council. Although required by law to meet at least ten times a year, the Governing Council in practice meets every two

5. The ESCB includes the ECB and the national central banks from all fifteen EU member states. At the time that the Maastricht Treaty was signed, it was generally understood that all EU countries would enter into EMU at the same time, and the Maastricht Treaty refers to the ESCB and not the Eurosystem. The national central banks of the member states that do not participate in the Eurosystem are members of the ESCB but have a special status; they are allowed to conduct their respective national monetary policies, and they do not take part in the decisionmaking regarding euro-area monetary policy and its implementation. 
3. Comparison of the organizational structure of the Eurosystem and the Federal Reserve System

\begin{tabular}{|c|c|c|}
\hline Item & Eurosystem & Federal Reserve System \\
\hline $\begin{array}{l}\text { Staffing } \\
\text { Total } \\
\text { At headquarters }\end{array}$ & $\begin{array}{l}53,000+ \\
500+\end{array}$ & $\begin{array}{l}24,500+ \\
1,700+\end{array}$ \\
\hline $\begin{array}{l}\text { Monetary policy decisionmaking } \\
\text { committee }\end{array}$ & The Governing Council & The Federal Open Market Committee \\
\hline $\begin{array}{l}\text { Number of members on the } \\
\text { monetary policy committee }\end{array}$ & $\begin{array}{l}\text { Seventeen: six members of the Executive } \\
\text { Board plus eleven governors of the national } \\
\text { central banks of EMU member states. }\end{array}$ & $\begin{array}{l}\text { Twelve: seven members of the Board } \\
\text { of Governors, plus the president of the } \\
\text { Federal Reserve Bank of New York, and } \\
\text { four of the remaining eleven regional } \\
\text { Federal Reserve Bank presidents rotating } \\
\text { on a one-year basis. }\end{array}$ \\
\hline Geographic representation & $\begin{array}{l}\text { No specific requirements for the six } \\
\text { Executive Board members. }\end{array}$ & $\begin{array}{l}\text { No more than one member of the Board } \\
\text { of Governors may be selected from any } \\
\text { of the twelve Federal Reserve Districts. }\end{array}$ \\
\hline Meeting frequency & $\begin{array}{l}\text { At least ten meetings per year required } \\
\text { by law. In practice, bi-monthly, every } \\
\text { other Thursday. }\end{array}$ & $\begin{array}{l}\text { At least four meetings per year required } \\
\text { by law. In practice, eight times per year. }\end{array}$ \\
\hline Publication of minutes & $\begin{array}{l}\text { Minutes accessible after thirty years. In } \\
\text { special cases, the Governing Council may } \\
\text { shorten this period. The president and the } \\
\text { vice president hold a press conference } \\
\text { following the first Governing Council } \\
\text { meeting of each month. }\end{array}$ & $\begin{array}{l}\text { Minutes released a few days after the } \\
\text { next regularly scheduled FOMC meeting } \\
\text { Lightly edited transcripts of all meetings } \\
\text { for a complete year released after a lag } \\
\text { of five years. }\end{array}$ \\
\hline $\begin{array}{l}\text { Regulatory and supervisory } \\
\text { responsibilities }\end{array}$ & $\begin{array}{l}\text { Most of the key prudential regulations } \\
\text { are harmonized in the EU. The primary } \\
\text { responsibility for supervision remains at } \\
\text { the national level. European Banking } \\
\text { Supervisory Committee of the ECB aims } \\
\text { to ensure coordinated supervision. }\end{array}$ & $\begin{array}{l}\text { Primary responsibility for supervising } \\
\text { and regulating all bank holding compa- } \\
\text { nies and their nonbank foreign subsidi- } \\
\text { aries, state-chartered banks that are } \\
\text { members of the Federal Reserve and } \\
\text { their foreign branches, and Edge Act } \\
\text { and agreement corporations. }\end{array}$ \\
\hline
\end{tabular}

weeks, a schedule similar to that employed by the German Bundesbank through December 1998.

\section{Objectives and Targets}

As specified in the Maastricht Treaty, the primary objective of the ECB is to "maintain price stability." Without jeopardizing this objective, the ECB is also expected to support the general economic policies of the European Commission. In this respect, the mandate of the ECB is similar to that of the Bundesbank. Section 3 of the Deutsche Bundesbank Act, which was signed into law in 1957 and later amended to comply with the Maastricht Treaty, names the main duties of the central bank as the regulation of the amount of money in circulation and of credit supplied to the economy with the aim of "safeguarding the currency." In practice, safeguarding the currency was interpreted to mean price stability. In comparison, the Federal Reserve Act states that U.S. monetary policy should seek "to promote effectively the goals of maximum employment, stable prices, and moderate long-term interest rates."
The ECB's published definition of price stability is inflation, measured as the twelve-month change in the harmonized index of consumer prices for the euro area, of below 2 percent-with no explicitly defined lower bound. ${ }^{6}$ Although the ultimate goal of euroarea monetary policy is clearly specified as price stability, the Governing Council of the ECB has adopted a flexible approach toward achieving this goal. Unlike the Bundesbank, which followed a specific intermediate target for a broad monetary aggregate, the Governing Council would-as Wim Duisenberg, president of the ECB, announced in October 1998-take into consideration a "reference value" for growth of a monetary aggregate and a mix of other indicators defined as "a broadly-based assessment of the outlook for future price develop-

6. Harmonized inflation for the euro area is calculated from a weighted average of harmonized consumer price indexes for individual countries. The harmonized indexes are constructed by standardizing some aspects of statistical practice and eliminating categories from national consumer price indexes, leaving indexes with basically identical coverage across countries. 
ments." 7 The relevant reference value for the central bank's monetary growth target, which was announced in December 1998 and is effective through December 1999 , is for areawide M3 growth of $4 \frac{1}{2}$ percent, as measured by a three-month moving average of the twelve-month percent change. In January 1999, the ECB noted that, among other things, the mix of other indicators will include wages, bond prices, the yield curve, measures of real activity, business and consumer surveys, and the exchange rate. ${ }^{8}$

To an important degree, the ECB's adoption of a flexible and pragmatic approach to monetary policy was influenced by a number of transitory constraints. During the initial stages, ECB officials were confronted with euro-area data that at times were incomplete and not fully harmonized, especially regarding historical data. Moreover, because national statistical agencies continued to publish the bulk of national statistics, there was a risk that financial markets might pay undue attention to developments in individual countries instead of those in the euro area as a whole. These constraints noted, the availability of timely and accurate euro-area data grew considerably in the first months of 1999. However, the "structural break" associated with monetary union provided another complication for interpreting and projecting basic economic relationships in the medium run, because both inflation and money growth relationships rely, explicitly or implicitly, on an understanding of the historical relationship between aggregate economic variables and the price level. Thus, the ECB's choice of a flexible approach to monetary policymaking was pragmatic. The need for the ECB to be flexible in the short run makes its policy setting less transparent. However, given the uncertainties about structural economic relationships during the transition, the ECB has chosen not to specify any intermediate target-at least, not until experience provides sufficient evidence that such a step would be productive.

\section{Implementation of Monetary Policy at the ECB}

Although decisions regarding monetary policy are made centrally by the Governing Council of the

7. For more details on Germany's use of monetary targets, see Linda S. Kole and Ellen E. Meade, "German Monetary Targeting: A Retrospective View," Federal Reserve Bulletin, vol. 85 (October 1995), pp. 917-31.

8. For further information on the ECB's monetary strategy, see "The stability-oriented monetary strategy of the Eurosystem," European Central Bank Monthly Bulletin (January 1999), pp. 39-51.
Eurosystem, the operational aspects of monetary policy implementation-including open market operations, administration of the minimum reserve system, and management of the standing facilities - are undertaken in a decentralized fashion at the eleven national central banks. The main features of the Eurosystem's operating procedures are similar in many respects to those employed by the Bundesbank and other national central banks in the euro area in recent years (see the box "Comparison of Eurosystem Monetary Operating Procedures with Those of the Bundesbank and the Federal Reserve System"). The Eurosystem provides liquidity to the euro-area banking system primarily through a weekly refinancing operation with a two-week maturity. ${ }^{9}$

Beginning with its first weekly tender settled on January 7 , the ECB has offered only fixed-rate tenders at its weekly refinancing operations. These tenders are bids by eligible banks for credit at the interest rate specified by the ECB. The Eurosystem then allocates the amount it decides to provide among the bids it has received. ${ }^{10}$ Individual banks are not restricted as to the volume of their bids, and they are required to have sufficient collateral to cover only the actual amount allocated. Additional liquidity is provided through longer-term monthly tenders that are conducted as variable-rate tenders with a three-month maturity. "Fine-tuning" operations may also be used to make further adjustments to the amount of liquidity in the market, although through June 30, no such operations had been undertaken.

The Eurosystem also has two standing facilities to provide and absorb overnight money and to provide a "corridor" for the market-determined interbank rate: the marginal lending facility and the deposit facility. The marginal lending facility provides overnight credit to all eligible credit institutions with sufficient collateral, and its interest rate usually serves as a ceiling for the overnight interbank rate. There is no stigma associated with borrowing at the marginal lending facility. However, such borrowing takes place at a penalty rate, in that the interest rate on the marginal lending facility is generally set between

9. The underlying securities for the weekly refinancing operations are predominantly euro-area government bonds and notes, but they also include shorter-maturity government securities and some privatesector securities. Each week, the ECB announces the list of securities that are eligible for use in monetary operations.

10. In this article, the terms bank and banking system are intended to include all euro-area credit institutions that are eligible to conduct operations with the Eurosystem. For further details, see European Central Bank, "The Single Monetary Policy in Stage Three: General documentation on ESCB monetary policy and procedures" (September 1998). 
100 and 150 basis points above the official weekly refinancing rate. The overnight interbank rate usually trades close to the weekly refinancing rate, giving banks an incentive to borrow in the interbank market if possible. Intra-day credit that is not repaid by the end of the day automatically rolls over to overnight lending through the marginal lending facility.

The second standing facility, the deposit facility, usually provides a floor for the interbank rate. This facility is available for banks to deposit excess funds

\section{Comparison of Eurosystem Monetary Operating Procedures with Those of the Bundesbank and the Federal Reserve System}

\section{EUROSYSTEM}

Primary Operations

The refinancing tender is a weekly repurchase operation with a two-week maturity. The tenders may be offered at a fixed or variable interest rate. To date, only fixed-rate tenders have been offered at the weekly refinancing operations. Allocated credit must be collateralized; eligible counterparties include all credit institutions subject to the Eurosystem's minimum reserve requirements that have sufficient collateral and that satisfy the operational criteria required by individual national central banks. The underlying securities for the weekly refinancing operations are predominantly euro-area government bonds and notes but also include shorter-maturity government securities and some private-sector securities. Each week, the ECB announces the list of securities that are eligible for use in monetary operations. Additional liquidity is provided through monthly refinancing operations. These are repurchase transactions at a three-month maturity, offered as variable-rate tenders of a fixed amount.

Standing Facilities

Marginal Lending Facility. The marginal lending facility is open to all eligible credit institutions with sufficient collateral for overnight credit from the Eurosystem. To date, the normal setting for the interest rate on the marginal lending facility is 100 to 150 basis points above the weekly refinancing rate.

Deposit Facility. The deposit facility is open to all eligible credit institutions for depositing excess funds overnight. To date, the normal setting for the interest rate on the deposit facility is 100 basis points below the refinancing rate.

\section{BUNDESBANK (before January 1, 1999)}

Primary Operations

From December 1993 through December 1998, the Bundesbank's primary monetary operations were conducted through weekly repurchase tenders with a two-week maturity, using either a fixed- or a variable-rate tender. The resulting "repo" rate was regarded as the most-important official interest rate. In general, the Bundesbank tended to use a variable-rate tender except during periods when it wanted to provide guidance to market interest rates. Between February 1996 and December 1998, the Bundesbank conducted only fixed-rate tenders.

\section{Standing Facilities}

Marginal Lending (Lombard) Facility. The Lombard facility was available for overnight credit from the Bundesbank for eligible credit institutions with sufficient collateral. The interest rate on the Lombard facility was normally set about 150 basis points above the repo rate. No stigma was associated with borrowing at the Lombard rate, but the facility was not intended as a permanent source of funding.

Discount Facility. Discount lending provided an additional source of liquidity at a subsidized rate, normally set about 100 basis points below the repo rate. Over time, the importance of the discount facility diminished; by 1996, it accounted for about one-third of central bank liquidity, down from nearly two-thirds in the mid-1980s.

\section{FEDERAL RESERVE SYSTEM}

\section{Primary Operations}

In contrast to the European Central Bank, the Federal Reserve System does not have an official repurchase rate at which it provides credit to the banking system. Instead, the Federal Reserve specifies as a target an intended level for the federal funds rate, which is the market overnight interbank borrowing rate, and conducts open market operations to influence the level of liquidity in the funds market to achieve that interest rate on average. Open market operations are conducted several times a week primarily in the form of variable-rate repurchase transactions of government securities, with a maturity ranging from one day to ninety days. Outright transactions in Treasury bills are also occasionally used.

\section{Standing Facility}

Discount Window. The discount window is a source of below-market-rate borrowing; borrowing at the discount window is normally restricted to banks that cannot obtain funds elsewhere at reasonable cost. 
that earn interest, although excess funds are not automatically swept into it. Normally, the interest rate on the deposit facility is 100 basis points below the refinancing rate. Thus, in normal times, the corridor provided by the marginal lending and deposit facilities is quite wide, at 2 percent to 2.5 percent. From January 4 through January 21, however, interest rates on the two standing facilities were set only 50 basis points apart -25 basis points on either side of the refinancing rate-to help ease distortions in the money market during the initial weeks of operations under the single currency.

\section{MACROECONOMIC BACKGROUND AND RECENT ECONOMIC DEVELOPMENTS IN THE EURO AREA}

The euro came into existence in an economic environment that turned out to be less than hospitable. Considerable downside risks to real economic activity were evident around the globe in the fall of 1998, stemming mainly from the Russian financial crisis in mid-1998, but also from the latter stages of the financial crisis in Asia and the signs of turmoil in Latin America. At the same time, the prolonged stagnation in Japan showed no signs of abating in the near term, and in the United Kingdom - a potential future entrant into the euro area-growth had slowed sharply from its previous robust pace. In contrast, U.S. economic activity continued to expand rapidly. ${ }^{11}$

Moreover, most European countries that were striving to meet the criteria of the Maastricht Treaty for EMU membership in the first round had undertaken significant fiscal tightening in 1997, the lagged effects of which, to some extent, carried over to 1998. The fiscal tightening, coupled with the negative effects of the Asian and Latin American crises on European foreign trade, brought early signs of a slowdown in Europe in the last quarter of 1998-the period in which final preparations for the launch of the euro were being made. Thus, given the robust pace of activity across the Atlantic, differences in cyclical economic positions set the stage for significant potential downward pressure on the exchange rate of the yet-to-be-born currency against the dollar.

Cyclical differences among countries heading into the final stage added another complication to the

11. To preserve the ongoing economic expansion in the United States, the Federal Open Market Committee responded to the increasing risks associated with weakening economic activity abroad and volatile conditions in financial markets in the autumn by reducing the intended federal funds rate a total of 75 basis points.
1. Output gaps for selected euro-area countries, 1996-98

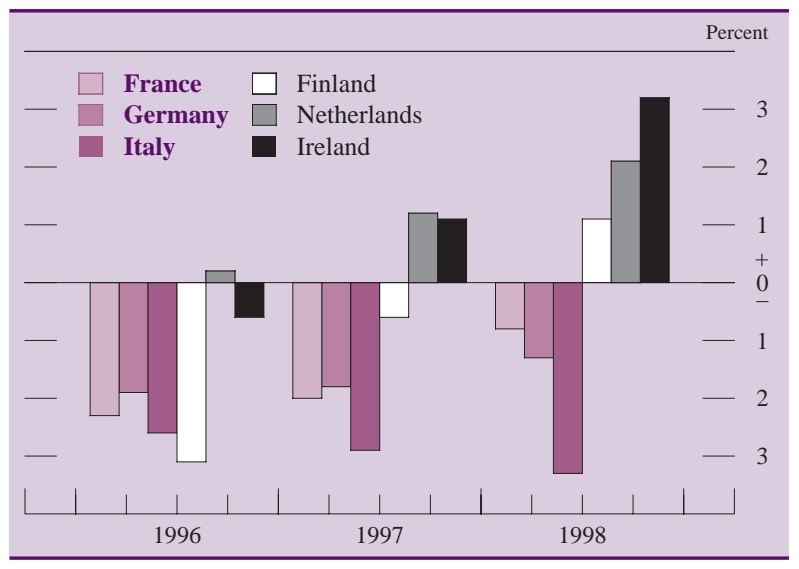

Note. The output gaps are the deviations of actual GDP from potential GDP as a percentage of potential GDP.

SourCE. OECD Economic Outlook, June 1999

economic picture. Economic activity in some countries, such as Germany and Italy, grew at only a moderate pace in 1998, while the economies of some other countries, notably Finland and Ireland, expanded rapidly. These differences could be seen in the increasing divergence in output gaps, a measure of unused capacity in the economy (chart 1). The differences became all the more relevant for the setting of monetary policy in light of the lower nominal interest rates brought about by convergence of official interest rates to levels prevailing in Belgium, France, Germany, and the Netherlands in the months leading up to January 1, 1999 (chart 2). Long-term interest rates had largely converged by early 1998, bringing forward some of the benefit of EMU (chart 3). In countries in which activity was already

2. Short-term interest rates for selected euro-area countries, January 1997-March 1999

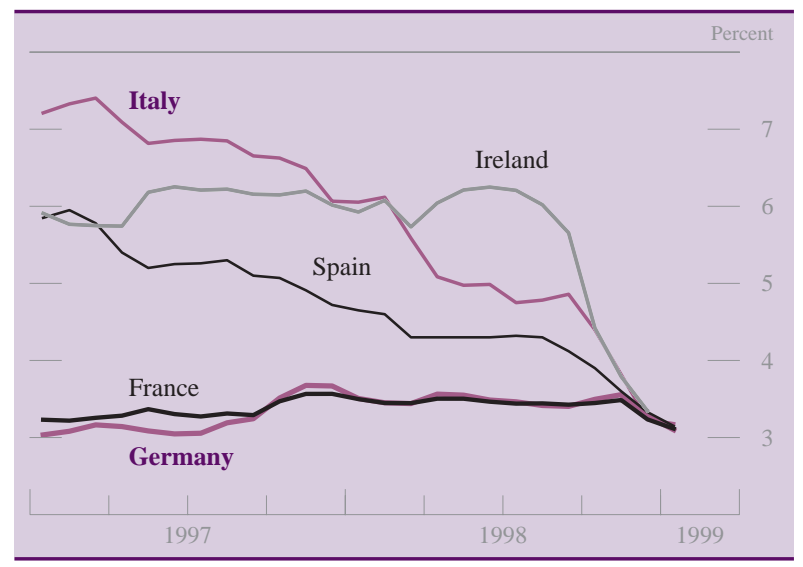

Note. The data are monthly averages. Short-term interest rates are threemonth interbank rates. 
3. Long-term interest rates for selected euro-area countries, January 1997-August 1999

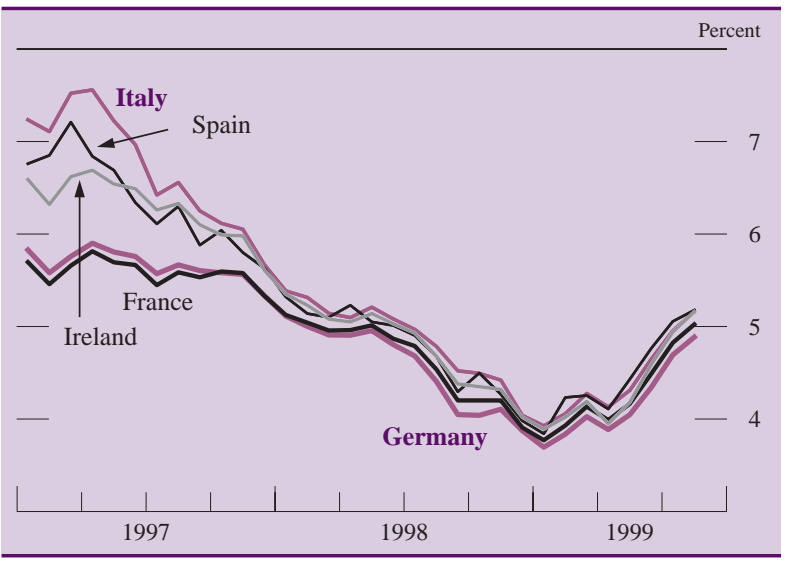

NotE. The data are monthly averages. Long-term rates are nominal ten-year (or closest available maturity) government bond yields.

robust, such as Ireland, the convergence process provided some additional marginal stimulus. ${ }^{12}$

\section{Recent Economic Developments and Policy Actions}

From mid-September through the end of December 1998 , the currencies of the eleven euro-area countries appreciated significantly against those of some trading partners, particularly against the U.S. dollar. After its inauguration on January 4, 1999, however, the new currency depreciated fairly steadily against other major currencies. By the end of July, the exchange value of the euro against the dollar had depreciated more than 13 percent from its initial value of 1.167 dollars per euro (see chart 4); recently it has reversed some of this depreciation. ${ }^{13}$

For the most part, the euro's steady weakening against the dollar was driven by differences in cyclical conditions between the euro area, where economic activity in the largest countries remained sub-

12. In early October, central banks in Spain and Portugal reduced official rates 50 basis points, and the Central Bank of Ireland cut rates 125 basis points. The Bank of Italy waited until December 28 before cutting its official rates 50 basis points to complete the process of convergence. A coordinated interest rate reduction by all prospective euro-area national central banks on December 3 provided additional stimulus. By January 1, the total weighted-average decline in euroarea rates that had occurred since September 1998 was about 75 basis points.

13. The fixing value of 1.16675 dollars per euro was determined by the value of the dollar-ECU exchange rate on December 31, 1998. However, when European financial markets opened on January 4, 1999, the euro traded at 1.1789 dollars per euro, an appreciation of about 1 percent relative to its fixing rate.
4. Exchange rate of the euro against the U.S. dollar, January 1996-August 1999

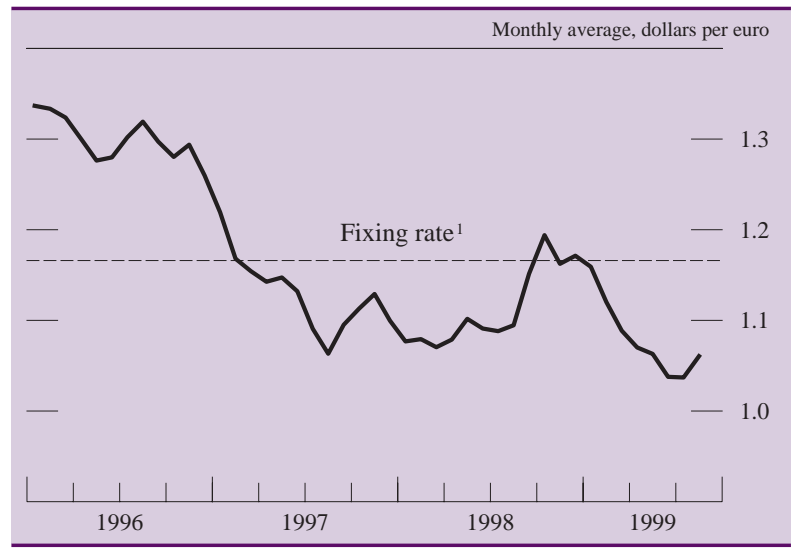

Note. The data are monthly averages. The exchange rate monthly data use the restated German mark before January 1999.

1. The fixing rate was set on December 31, 1998, at 1.16675 U.S. dollars per euro.

dued, and the United States, where economic activity was still robust. The weaker euro provided some stimulus to euro-area foreign trade, although in evaluating the potential effects of the depreciation of the euro against other major currencies, namely the U.S. dollar and the U.K. pound, it is useful to note that once intra-euro-area trade is excluded, the euro-area economy is relatively closed compared with the individual economies of the eleven countries before the adoption of the euro (see table 1). Thus, larger movements in the value of the euro may be necessary to affect areawide economic activity than the move-

5. Monetary Union Index of Consumer Prices (MUICP) for the euro area, January 1997-June 1999

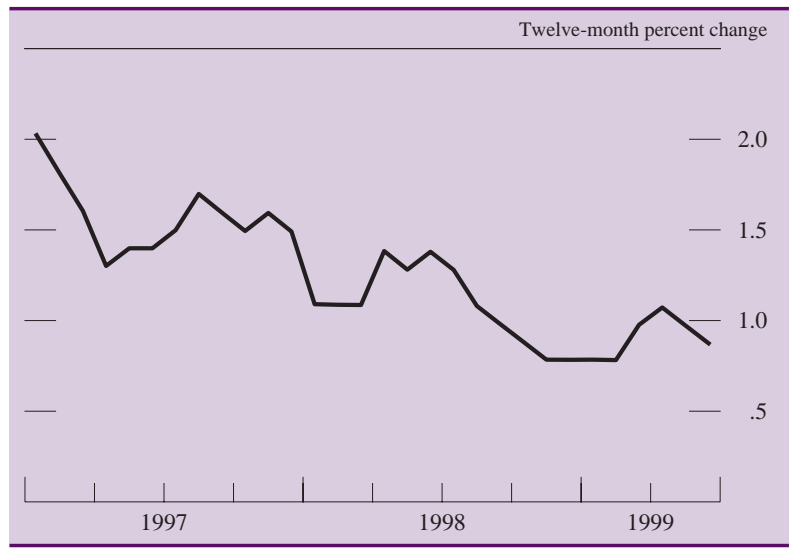

Note. The data are monthly averages. The MUICP is calculated as a weighted average of harmonized consumer price indexes of the euro-area countries. The harmonized indexes are constructed by standardizing some aspects of statistical practice and eliminating categories from national consumer price indexes, leaving indexes with basically identical coverage across countries. Country weights are calculated every year from the country's share of private final domestic consumption expenditure in the euro-area total (from Eurostat). 
6. Harmonized M3 growth for the euro area, October 1997-June 1999

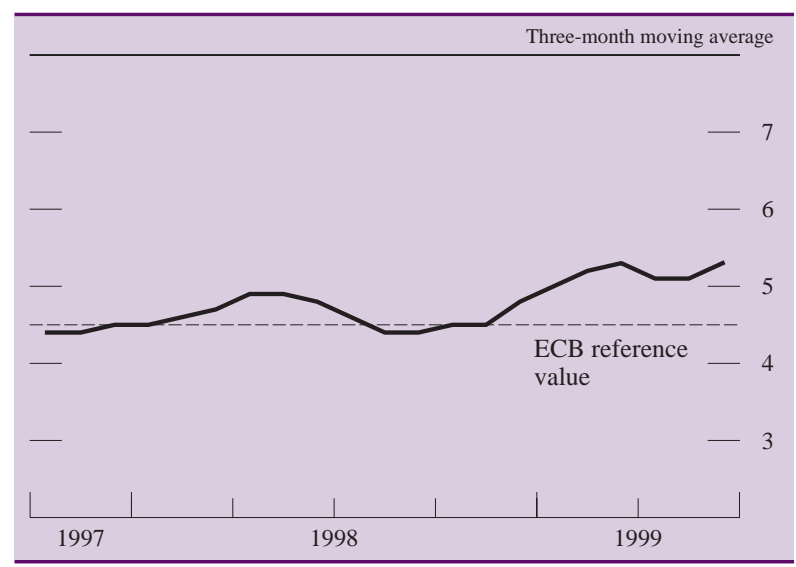

NotE. The data are monthly averages. Euro-area harmonized series are compiled by the European Central Bank based on monthly reporting by monetary financial institutions in each country.

ments that had to occur for national currencies to affect their respective national economies.

At its meeting on April 8, the Governing Council of the ECB responded to the emerging evidence of weaker activity in the euro area by cutting official interest rates. The Governing Council reduced the refinancing rate 50 basis points, to $2 \frac{1}{2}$ percent, which was more than market participants had expected, and also cut the marginal lending rate and deposit rates 100 basis points and 50 basis points, respectively, to $3 \frac{1}{2}$ percent and $1 \frac{1 / 2}{2}$ percent. These actions marked the first change in the policy stance by the ECB, although official interest rates had been reduced to 3 percent last December by the national central banks of prospective members of the Eurosystem. The moves were made possible to a significant extent by the lack of price pressures in the euro area, as consumer price inflation remained well below the ECB's official ceiling of 2 percent (chart 5). Although euroarea M3 growth hovered around 5 percent on a twelve-month basis, slightly above the ECB reference value of $4 \frac{1}{2}$ percent for M3 growth (chart 6), the Governing Council noted that these developments likely reflected the unwinding of special factors relating to the start of EMU and consequently did not consider them to be a signal of future inflationary developments.

\section{Early Developments in Money Markets}

Besides the challenges of determining the appropriate monetary stance for the euro area as a whole in the uncertain environment of early 1999, Eurosystem
7. Eurosystem interest rates, January-August 1999

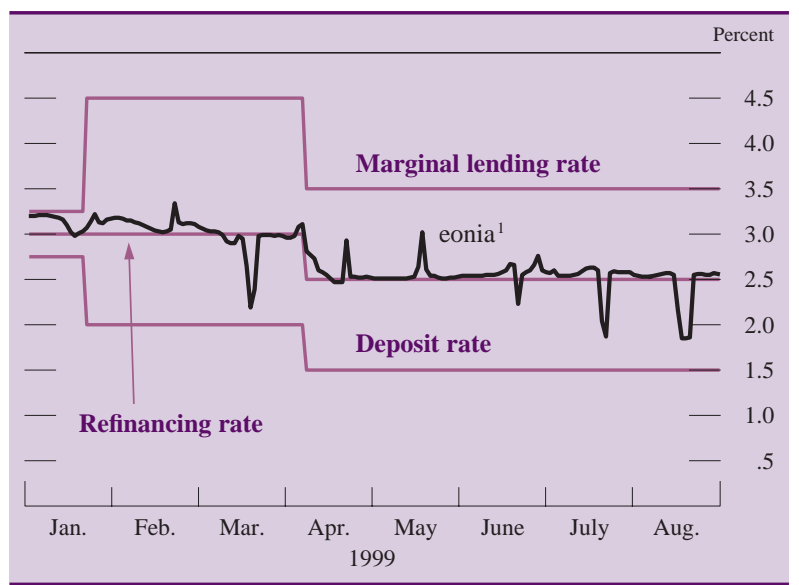

Note. The data are monthly averages.

1. Euro overnight index average.

officials faced challenges in ensuring that monetary policy was implemented smoothly and effectively throughout the Eurosystem. Early in 1999, overnight market interbank rates in the euro area, as measured by the euro overnight index average (eonia), traded close to the official marginal lending rate, suggesting some interbank liquidity strains (chart 7). Also, according to ECB President Duisenberg, the spread

8. Daily use of Eurosystem standing facilities, January-August 1999

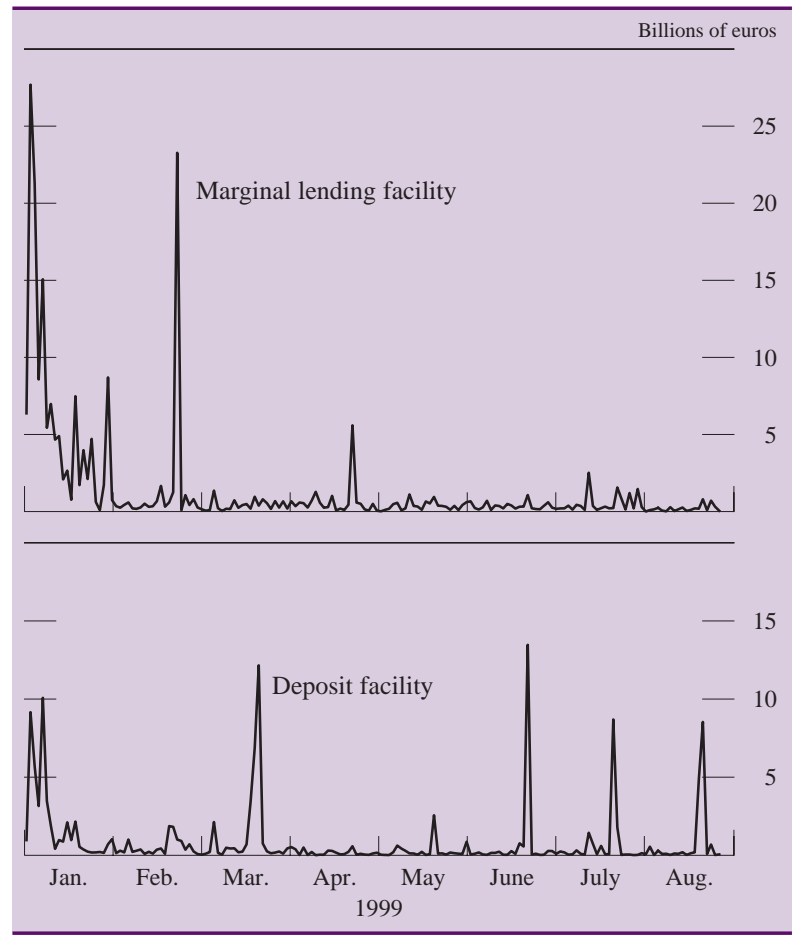


between interbank rates in different countries was larger than should be considered normal for a single currency area: The spread was as much as 21 basis points on January 4; by January 18 , however, it had narrowed to less than 10 basis points. Initially, the use of both standing facilities, especially that of the marginal lending facility, was high (chart 8). In part, the unusually heavy use of the marginal lending facility likely reflected the relatively high cost of funds in the interbank market as well as some start-up difficulties with the Eurosystem's wholesale payment system. Heavy use of the deposit facility also indicated payment system problems. As these difficulties have been resolved, use of the marginal lending facility and the deposit facility has decreased, and the overnight rate has generally traded close to the refinancing rate, with major deviations only at the ends of reserve maintenance periods.

\section{DEVELOPMENTS IN EUROPEAN FINANCIAL SYSTEMS AND MARKETS}

\section{Wholesale Payment Systems}

One of the biggest challenges for the successful implementation of monetary policy under the single currency was the creation of a wholesale payment system that would enable transactions to be conducted quickly and efficiently across borders and would facilitate integration of money markets in the euro area. Since January, the majority of the domestic and cross-border euro payments have been sent through the TARGET (Trans-European Automated Real-time Gross-settlement Express Transfer) system. TARGET consists of a real-time gross settlement (RTGS) system for funds transfer in each of the fifteen EU countries (including the EU countries not currently participating in EMU), the ECB's payment mechanism, and an interlinking among all the component systems. ${ }^{14}$

Credit institutions in member countries may obtain central bank credit only from the national central bank in the country in which they are based, but they may use TARGET to conduct interbank operations across the EU area. About 5,000 credit institutions have direct access to one of the fifteen euro RTGS systems in the EU and, through the TARGET inter-

14. Alternative payment systems include non-RTGS German and French systems, which run frequent net settlements throughout the day, and the EU-wide Euro1 system run by the Euro Banking Association, which is an end-of-day, multilateral net settlement system. linking, to each other. Some of the distortions that arose in the money market during the first few weeks reflected "teething problems" with TARGET, as noted by ECB President Duisenberg. Payments occasionally were incorrectly routed or otherwise mishandled and subsequently rejected by TARGET, and resulting positions at the relevant banks were often not resolved until the end of the day, requiring the banks to resort to the automatic conversion of intraday drafts to overnight loans at the marginal lending facility. In response to some of these payment system difficulties, TARGET settlement was extended an hour each day for most of January, but a penalty was imposed to discourage late settlement. ${ }^{15}$ Overall, the functioning of TARGET as an EU-wide payment system has been quite successful: In the first quarter of 1999, it processed a daily average of more than 150,000 transactions valued at 966 billion euros (\$1,081 billion). ${ }^{16}$

\section{Securities Settlement Systems}

In contrast to the relatively quick establishment of a wholesale payment system to handle a large volume of cross-border transactions, the consolidation of securities settlement systems remains limited. Most systems serve only their domestic securities markets, with multiple systems existing within some countries. Differences across the euro area in legal arrangements applying to securities holdings and transactions have also made integration of securities settlement systems more difficult. To help compensate for inadequacies in market structures and to ensure that all banks in the euro area have equal access to eligible collateral when borrowing from the national central banks (NCBs), the Eurosystem has established a system to transfer securities through the so-called Correspondent Central Bank Model. Under this arrangement, a bank in one country may pledge securities eligible for collateral but held in another country by arranging for those securities to be transferred to a custodial account at the NCB of that country and notifying the home NCB of its intent. Once the home NCB receives acknowledgment from the custodial NCB that the securities transfer is com-

15. For further details on TARGET and developments in wholesale payment and securities settlement systems, see Bank of England, Practical Issues Arising from the Euro (June 1999).

16. By way of comparison, over the same period, the Federal Reserve System's Fedwire service, available to approximately 10,000 U.S. depository institutions, processed a daily average of more than 400,000 funds transfers with a daily average value of $\$ 1,343$ billion. 
plete, it authorizes the credit. However, increasing integration of European capital markets and greater demand for cross-border securities trading and settlement are expected in time to lead to an integrated European securities settlement system. In particular, the Eurosystem has encouraged the development of links among securities settlement systems. Twentysix links already allow for transfers of securities from one system to another, and further links and other projects to integrate the securities settlement structure are under development. ${ }^{17}$

\section{Debt Markets}

To date, debt markets have reacted favorably to the new currency. ${ }^{18}$ The value of new issues of eurodenominated international bonds and notes accounted for about 38 percent of all new international bonds in the first two quarters of $1999 .{ }^{19}$ The share is considerably larger than in 1998, when new issues of international bonds denominated in the eleven national legacy currencies and the ECU accounted for about 27 percent of all new international issues. ${ }^{20}$ Of all new issues denominated in the euro, most are domestic bonds issued by euro-area governments. Although yields on long-term government bonds of the member countries continued to converge through 1998,

17. Some of the legal issues surrounding securities transactions should be clarified by the Settlement Finality Directive, due to be implemented by all EU members by December 1999. This directive addresses systemic risk in payment and settlement systems primarily, but it also covers some legal aspects of cross-border use of collateral.

18. For further details on developments in euro-area debt and equity markets, see Bank of England, Practical Issues Arising from the Euro (June 1999) and European Central Bank, "The international role of the euro," European Central Bank Monthly Bulletin (August 1999), pp. 32-53.

19. New issues of U.S. dollar-denominated bonds accounted for almost half of all new international issues in the first two quarters of 1999, a share slightly lower than that in 1998. Conclusions about the relative shares of euro- and U.S. dollar-denominated new issues are influenced importantly by the definitions of bonds included in the comparison. The definition used in this article includes issues denominated in a currency other than that of the country in which the borrower resides, and issues in domestic currency where the targeted investor resides outside the country of the issuer's residence. For further details, see Bank for International Settlements, Quarterly Review: International Banking and Financial Market Developments (August 1999).

20. The official ECU was a weighted market basket of twelve EU currencies established in connection with the EMS. The composition of the basket was fixed in January 1994, and currencies of countries that joined the EU subsequent to January 1994 (the Austrian schilling, the Finish markka, and Swedish krona) were not included in the ECU. Thus, the ECU currency basket included nine euro-area currencies as well as the British pound, the Danish kroner, and the Greek drachma. On January 1, 1999, holdings of the official ECU were converted one for one to the euro.
4. Sovereign credit ratings and government bond spreads for euro-area countries

\begin{tabular}{|c|c|c|c|}
\hline \multirow{2}{*}{ Country } & \multicolumn{2}{|c|}{$\begin{array}{l}\text { Credit rating, } \\
\text { long-term debt }\end{array}$} & \multirow{2}{*}{$\begin{array}{c}\text { Spread over } \\
\text { German } \\
\text { long-term } \\
\text { government } \\
\text { bonds } \\
\text { (basis points, } \\
\text { June } 1999 \\
\text { average) }\end{array}$} \\
\hline & Moody's & $\begin{array}{l}\text { Standard \& } \\
\text { Poor's }\end{array}$ & \\
\hline Austria . & Aaа & AAA & 18 \\
\hline Belgium & Aal & $\mathrm{AA}+$ & 28 \\
\hline Finland & Aaa & $\mathrm{AA}+$ & 22 \\
\hline France & Aaa & $\mathrm{AAA}$ & 11 \\
\hline Germany . & Aaa & AAA & \\
\hline Ireland $\ldots$ & Aaa & $\mathrm{AA}+$ & 23 \\
\hline Italy & $\mathrm{Aa} 3$ & AA & 26 \\
\hline Luxembourg & Aaa & AAA & 1 \\
\hline Netherlands & Aaа & $\mathrm{AAA}$ & 15 \\
\hline Portugal .... & $\mathrm{Aa} 2$ & $\mathrm{AA}$ & 28 \\
\hline Spain ... & $\mathrm{Aa} 2$ & $\mathrm{AA}+$ & 25 \\
\hline
\end{tabular}

some differentials remain, reflecting differences across member countries in credit ratings and market liquidity (table 4). The introduction of the single currency has led to competition for "benchmark" status among euro-denominated bonds. ${ }^{21}$ At the moment, ten- and thirty-year German government bonds are emerging as the euro benchmark issues, although some market firms use French government securities for reference at shorter maturities.

In general, European corporate debt markets are less developed than those in the United States, and corporate financing is more heavily weighted toward bank financing. Corporate debt markets account for only about 26 percent of corporate financing in the EU area, compared with 68 percent in the United States. Creation of the single currency area appears to be helping development of this sector, with recent increases in issuance of less-than-AA-grade bonds, especially in the second quarter, although issuance of so-called junk bonds remains uncommon. ${ }^{22}$

Financing of heavy merger and acquisition activity, brought about in large part by the cross-border opportunities provided by EMU, has also led to increased corporate issuance, while low bond yields in the first half of the year made bond issuance especially attractive. The introduction of the euro has also benefited the German Pfandbriefe market for "secured" asset-backed bonds issued primarily by banks and mortgage institutions. Jumbo issues of

21. Benchmark bonds are traditionally of very high credit quality and are easily and widely traded. They tend to be larger issues, which are usually more liquid at any given maturity.

22. Junk bonds are bonds rated BB+ or lower by Standard and Poor's or Ba1 and lower by Moody's. 
more than a billion euros have become more common, and the distribution is much wider than it was previously. Foreign investors are increasingly active in this market; they hold 15 percent to 20 percent of the total outstanding in these jumbo bonds and have increased their investment in recent issues.

Among nondomestic currency issues, European countries outside the EU accounted for many of the new euro-denominated issues in the first quarter of 1999. More recently, several emerging-market governments have substantially increased eurodenominated issues, especially in the second quarter, reflecting higher yields and more volatility in the dollar market. In early July, Brazil successfully launched a sizable euro-denominated issue, and Argentina indicated that for the remainder of the year, it did not intend to issue debt in U.S. dollars and would turn instead to the euro market.

\section{Equity Markets}

Early indications are that EMU is also serving as a catalyst for changes in equity markets. Traditionally, divergence has been considerable across the euro area in the mix of bonds versus equities in institutional portfolio allocations, with a relatively low average share for equities of less than 10 percent in Germany and a considerably higher share, of about 50 percent, in other euro-area countries such as the Netherlands. Surveys suggest that European fund managers intend to rebalance portfolios or redirect new flows of funds, in terms of both the bond-equity split and geographic diversification. Increasing interest in Europe-wide investment opportunities has led to a proliferation in equity indexes in the past couple of years, both in euro-area indexes and in "PanEuropean" indexes that also include Swiss and U.K. companies; however, as yet no index has emerged as a clear benchmark.

\section{Developments in European Banking}

Most of the developments in banking in the euro area have taken the form of consolidation within individual euro-area countries, and from the mid-1980s, the number of European credit institutions declined substantially. Between 1985 and 1997, for example, the number of banks declined 24 percent in Germany, 38 percent in France, 40 percent in Spain, and 19 percent in Italy. ${ }^{23}$

23. By way of comparison, the number of banks decreased 37 percent in the United States during the same period.
Most of these merger and acquisition activities involved relatively small institutions, such as savings banks, credit cooperatives, and mutual banks. More recently, however, merger and acquisition activity involving larger institutions has become increasingly important, and from the 1991-94 period to the 1995-98 period, the average value of merger and acquisition transactions increased almost tenfold.

Although bank mergers in the larger continental European countries continue to occur primarily within national boundaries, cross-border bank acquisitions between banks in geographically close countries have become more common in the past four years. Intra-European transactions have been undertaken mainly in the Nordic and Benelux countries, leading to the emergence of regional banking markets in these areas. In addition, several cross-border purchases of equity holdings in banks have recently occurred: Large Dutch, German, and French banks have purchased important stakes in large Spanish and Italian banks. Although less spectacular than recent large acquisitions within some countries, these purchases signal further steps toward the integration of European banking.

Such developments in European banking have been driven by several fundamental forces of change that swept through the international financial system, including financial liberalization, technological advances, and global diversification of savings and investment portfolios. These factors are likely to continue to reshape banking in Europe. The final stage of European economic and monetary union, which has already helped raise the potential profitability of economies of scale and scope across Europe, is likely to lead to further structural changes and more competition in the banking sector.

\section{USE OF THE EURO FOR TRANSACTIONS AND AS A RESERVE CURRENCY}

Euro-area countries expect to circulate eurodenominated notes and coins beginning January 1, 2002. Until then, and for six months following that date, national currencies will continue to circulate as legal tender. Because the euro does not yet exist in physical form, it can be used only for noncash transactions. However, prices may be quoted in euros, and cash transactions can be conducted in the national currencies using the official convergence rates (table 2). In the current transition period before the introduction of euro currency, businesses are encouraged to quote prices in both the national currency and euros. Surveys suggest that the current use of euro 
pricing remains limited and that considerable differences exist across countries. For example, Dun and Bradstreet in April 1999 found that only about 30 percent of the 2,040 businesses surveyed in the euro area responded that they had started quoting prices in euros, ranging from a high of about 40 percent in Luxembourg and Austria to only about 10 percent in Portugal. A majority of businesses responded that they planned to begin pricing in euros by the end of 2000, but few expected to be pricing solely in euros before 2002. Anecdotal evidence suggests that dual pricing is more prevalent in the financial sector and at the retail level.

The creation of a single European currency has led to speculation that the euro could eventually challenge the U.S. dollar in importance as an international reserve currency. In terms of official reserves, at the end of 1998 the U.S. dollar accounted for about 60 percent of total official holdings of foreign exchange. Holdings of the legacy currencies of the euro-area countries accounted for about 14 percent, with the single largest share of such currency holdings in the deutsche mark. About 1 percent of reserves were also held in market instruments denominated in the ECU. ${ }^{24}$ Although no comprehensive details are currently available on total official holdings of the euro so far this year, the share of the euro in total official holdings has probably declined relative to the share held in the legacy currencies and in ECUs. A significant portion of official reserves held in these currencies, primarily in the deutsche mark, was held by other euro-area NCBs, and with the conversion of these assets to the euro, they are no longer classified as foreign exchange reserves. However, holdings of the euro currently account for about half of U.S. official reserves and are an even larger share in the official foreign exchange portfolios of some nonparticipating EU countries, such as the United Kingdom. ${ }^{25}$

24. On December 31, 1998, the Eurosystem converted into gold and U.S. dollars the official ECUs that had been issued to EU central banks through revolving swaps in exchange for 20 percent of their gross gold holdings and U.S. dollar reserves. Such ECUs amounted to about 4 percent of international official reserves at the end of September 1998.

25. For details on the currency composition of U.S. official foreign exchange reserves, see Laura F. Ambroseno, "Treasury and Federal Reserve Foreign Exchange Operations," Federal Reserve Bulletin, vol. 85 (September 1999), pp. 616-20. For details on U.K. official foreign exchange reserves, see the U.K. Treasury press release, "Quarterly Report on UK Official Holdings of Foreign Currency and Gold: April-June 1999.'
In private-sector use, the dollar remains the preeminent currency in international financial transactions. The Bank for International Settlements triennial central bank survey in 1998 of foreign exchange and derivatives market activity reports that a significant majority ( 87 percent) of "traditional" foreign exchange transactions involved exchanges of U.S. dollars for another currency. ${ }^{26}$

Use of the deutsche mark accounted for about 30 percent of "traditional" transactions. In the smaller, but rapidly growing, over-the-counter derivatives market, transactions involving the deutsche mark grew especially quickly in recent years. Because many of these transactions were between the deutsche mark and other euro-area legacy currencies, it is difficult to infer from these statistics the current importance of the euro in international financial transactions.

Over time, the use of the euro as a means of making international payments may well increase. For example, with the introduction of euro notes and coins in 2002, residents of countries with emerging financial markets that currently conduct financial transactions using the U.S. dollar may begin to use the euro instead, especially in countries that are near the euro area and that trade more extensively with the euro area than with the United States. Recent developments in European financial markets are also encouraging for the euro's future prospects as a major international currency. As euro-area markets become more fully integrated, the euro is likely to play an increasing role in international financial transactions.

26. To some extent, this figure is inflated by the rise in the exchange value of the dollar in recent years. In constant-dollar terms, the dollar's role on one side of foreign exchange transactions still remains slightly above 75 percent of all transactions. For further details on the survey, see Bank for International Settlements, "Central Bank Survey of Foreign Exchange and Derivatives Market Activity 1998" (May 1999). 